University of Nebraska - Lincoln

DigitalCommons@University of Nebraska - Lincoln

1995

\title{
Effects of Climate on Numbers of Northern Prairie Wetlands
}

Diane Larson

USGS Northern Prairie Wildlife Research Center, dlarson@usgs.gov

Follow this and additional works at: https://digitalcommons.unl.edu/usgsnpwrc

Part of the Other International and Area Studies Commons

Larson, Diane, "Effects of Climate on Numbers of Northern Prairie Wetlands" (1995). USGS Northern Prairie Wildlife Research Center. 81.

https://digitalcommons.unl.edu/usgsnpwrc/81

This Article is brought to you for free and open access by the US Geological Survey at DigitalCommons@University of Nebraska - Lincoln. It has been accepted for inclusion in USGS Northern Prairie Wildlife Research Center by an authorized administrator of DigitalCommons@University of Nebraska - Lincoln. 


\title{
EFFECTS OF CLIMATE ON NUMBERS OF NORTHERN PRAIRIE WETLANDS *
}

\author{
DIANE L. LARSON \\ National Biological Survey, Northern Prairie Science Center, 8711 37th St. SE, Jamestown, \\ ND 58401, U.S.A.
}

\begin{abstract}
The amount of water held in individual wetland basins depends not only on local climate patterns but also on groundwater flow regime, soil permeability, and basin size. Most wetland basins in the northern prairies hold water in some years and are dry in others. To assess the potential effect of climate change on the number of wetland basins holding water in a given year, one must first determine how much of the variability in number of wet basins is accounted for by climatic variables. I used multiple linear regression to examine the relationship between climate variables and percentage of wet basins throughout the Prairie Pothole Region of Canada and the United States. The region was divided into three areas: parkland, Canadian grassland, and United States grassland (i.e., North Dakota and South Dakota). The models - which included variables for spring and fall temperature, yearly precipitation, the previous year's count of wet basins, and for grassland areas, the previous fall precipitation - accounted for 63 to $65 \%$ of the variation in the number of wet basins. I then explored the sensitivities of the models to changes in temperature and precipitation, as might be associated with increased greenhouse gas concentrations. Parkland wetlands are shown to be much more vulnerable to increased temperatures than are wetlands in either Canadian or United States grasslands. Sensitivity to increased precipitation did not vary geographically. These results have implications for waterfowl and other wildlife populations that depend on availability of wetlands in the parklands for breeding or during periods of drought in the southern grasslands.
\end{abstract}

\section{Introduction}

The highly productive closed basins typical of the Prairie Pothole Region provide breeding and brood-rearing habitat for more than half of North America's waterfowl population (Batt et al., 1989). Yearly population estimates of many duck species closely track the number of wet basins within the region (Johnson and Grier, 1988; Batt et al., 1989). An understanding of the contribution climate makes to wetland numbers is increasingly important as we enter a period of potentially enhanced greenhouse warming. Although considerable uncertainty exists in projections of climatic change (Cess et al., 1993), general circulation models agree that temperatures will rise in the northern Great Plains (Smith and Tirpak, 1990; Karl et al., 1991a). There is less agreement on potential changes in precipitation, but most climate models piedict a slight net annual increase (Karl ¿t al., 1991a; see also Poiani and Johnson, 1991).

The number of wetland basins holding water during any year is a function of physical properties of the site such as soil permeability, groundwater flow, and

* The U.S. Government right to retain a non-exclusive, royalty-free license in and to any copyright is acknowledged. 
basin size, as well as climatic effects such as temperature and precipitation (Meyboom, 1966; Shjeflo, 1968; Winter, 1989; Poiani and Johnson, 1991). The relative importance of each of these factors for water accumulation and retention has been studied for only a few wetlands (Winter, 1989) and may vary geographically. Because settling patterns of duck species throughout the Prairie Pothole Region vary and depend on local wetland conditions (Johnson and Grier, 1988), understanding geographic variation in wetland response to climate is a critical step in anticipating the effects a changing climate might have on waterfowl populations. The purpose of this paper is to (1) report on regression models relating number of wet basins to climate variables throughout the Prairie Pothole Region; (2) explore the potential effects of temperature and precipitation changes on number of basins holding water; (3) compare sensitivities of wetlands in different geographic areas of the Prairie Pothole Region to climate; and (4) examine implications for waterfowl breeding in the Prairie Pothole Region.

The following definitions apply in this paper. Prairie Pothole Region refers to the geographic area extending south from the border of the boreal forests in Manitoba, Saskatchewan, and Alberta to the southernmost extent of the Wisconsin glaciation in North Dakota and South Dakota. The region is unified by an abundance of glacial depressions, but can be subdivided by predominant vegetation: parkland, in which basins are surrounded by aspen and willow, and grassland, where mixed-grass prairie predominates. Wetland basins are glacially formed depressions, also known as potholes, that may or may not hold water in any given year; hereafter I refer to them simply as basins. Wet basins are those holding water during aerial surveys described below. Wetland classification follows Stewart and Kantrud (1971).

\section{Methods}

Models were developed using data from the annual May waterfowl breeding population and habitat surveys conducted by the United States Fish and Wildlife Service and the Canadian Wildlife Service (Henny et al., 1972). These surveys are made from aircraft flown at an elevation of 30 to $50 \mathrm{~m}$ above ground along transects traversing strata of similar habitat (Figure 1); both ducks and wet basins are counted. All seasonally and semipermanently flooded basins holding water are counted on one side of the transect to a distance of $200 \mathrm{~m}$. Temporary wetlands and sheet water are not counted. Only those strata occurring within the Prairie Pothole Region for which transect end points could be obtained were used in model development (Table I). I used data from strata 34 and 35 for model testing because the latitudes and longitudes of the transect end points became available after models were completed. Because I did not know the total number of basins on each transect, I set the largest number counted on each transect for the period covered by the data to $100 \%$. Strata were classified as parkland or grassland according to Kiel et al. (1972) as modified by Sargeant et al. (1993). Grassland was further divided 


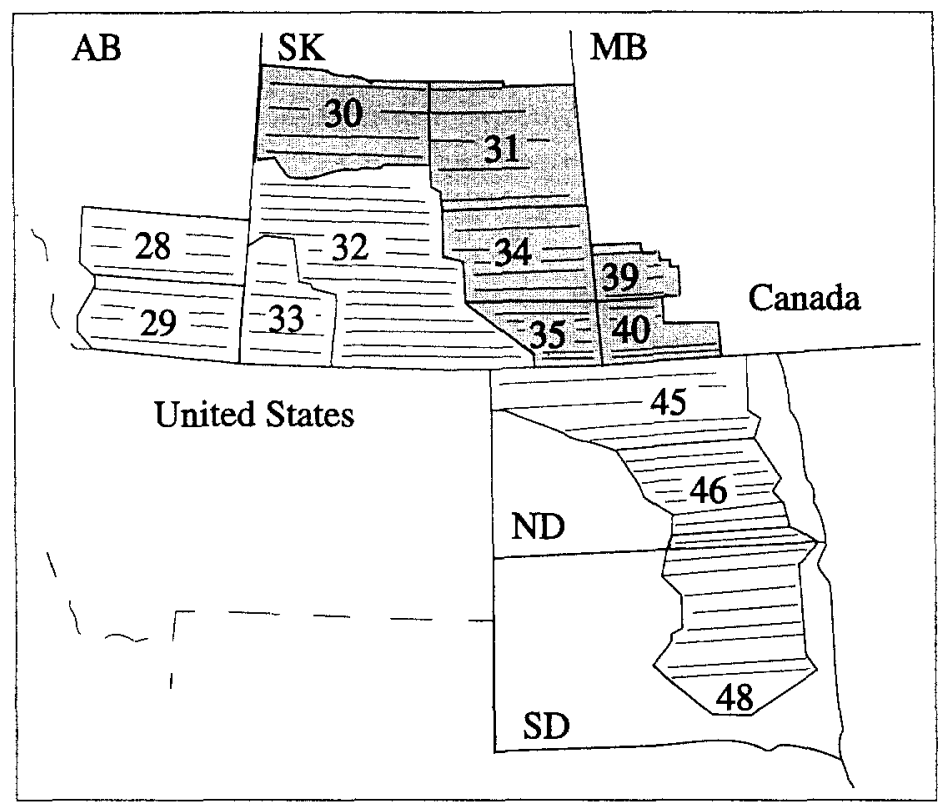

Fig. 1. Study area used in model construction and validation. Shaded areas are parkland; unshaded areas are grassland. Horizontal lines are aerial transect locations. Numbers are stratum designations.

into Canadian and United States transects because counts of wet basins started later in the United States, and the climate data for the two countries came from different sources and included somewhat different variables. I excluded strata that could not be categorized as either grassland or parkland (e.g., transition forest). The Canadian grassland and parkland models were developed with data from 1968 through 1990; the United States grassland model was developed with data from 1973 through 1987. Each data set included relatively wet and dry, and warm and cool years (Figure 2).

United States climate data were obtained from the Historic Climatology Network (Karl et al., 1990) and included monthly minimum, maximum, and mean temperatures and monthly total precipitation. Canadian climate data were obtained from the Canadian Climate Centre and included the same variables as the United States data plus monthly snowfall accumulations. I produced monthly grids for each variable for each year, using ordinary kriging (Isaaks and Srivastava, 1989) with the software package Surfer (Golden Software, Inc., 1991) to geographically interpolate data. From these grids I sampled 10 randomly selected points on each transect, whose values were then averaged to obtain a mean value for each month of each year on each transect. The same 10 locations on each transect were used throughout.

I used multiple linear regression to examine the relationship between climate variables and percentage of wet basins for the three geographic regions: parkland, 
TABLE I

Geographic areas within the Prairie Pothole Region used in model development

\begin{tabular}{|c|c|c|c|c|c|}
\hline \multirow{2}{*}{$\begin{array}{l}\text { Model } \\
\text { region }\end{array}$} & \multirow{2}{*}{$\begin{array}{l}n \\
\text { transects }\end{array}$} & \multirow{2}{*}{$\begin{array}{l}\text { Maximum } \\
\text { basins }^{1}\end{array}$} & \multicolumn{2}{|c|}{ Area $\left(\mathrm{km}^{2}\right)$} & \multirow{2}{*}{$\begin{array}{l}\text { Basin } \\
\text { density }^{2}\end{array}$} \\
\hline & & & Total & Sampled & \\
\hline Parkland & 17 & 13,025 & 131,427 & 1259 & 10.35 \\
\hline $\begin{array}{l}\text { Canadian } \\
\text { grassland }\end{array}$ & 28 & 10,343 & 195,237 & 2506 & 4.13 \\
\hline $\begin{array}{l}\text { United States } \\
\text { grassland }\end{array}$ & 20 & 8,019 & 169,515 & 2319 & 3.46 \\
\hline
\end{tabular}

Maximum number of wet basins counted during aerial transect surveys for the time period covered by the model: 1968-90 for parkland and Canadian grassland, 1973-87 for United States grassland.

2 Basins $/ \mathrm{km}^{2}$ within sampled area.
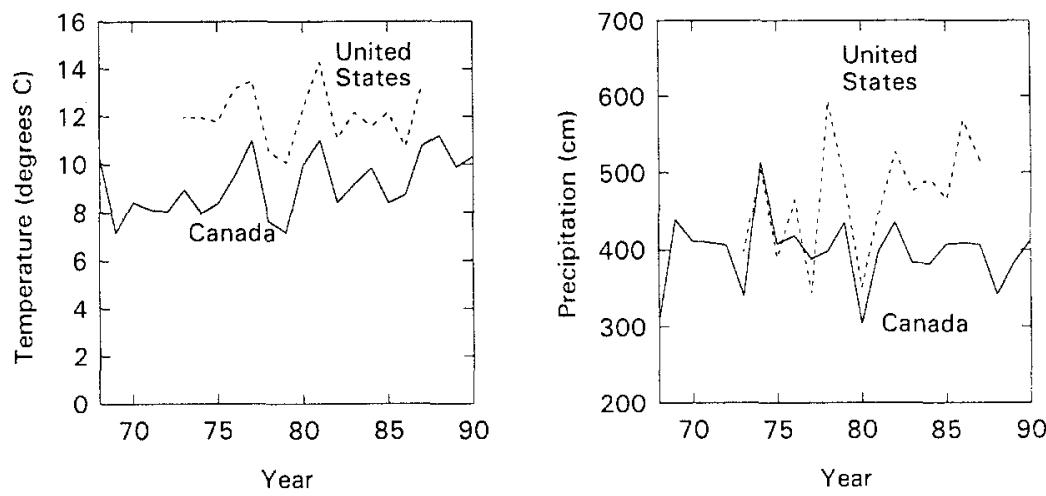

Fig. 2. Average annual maximum temperature and total annual precipitation for study areas in Canada (solid line) and the United States (dashed line) during the years used in model development (1973-1987 for United States; 1968-1990 for Canada).

Canadian grassland, and United States grassland. Explanatory variables included minimum, maximum, and mean monthly, seasonal, and annual temperature; total monthly, seasonal, and annual precipitation; monthly snowfall (in Canada); and the number of wet basins counted the previous May. The effects of one- and twoyear lags were examined for the seasonal and annual data. Two moisture indices were also examined, the Thornthwaite moisture index (McCabe and Wolock, 1991) and a conserved soil moisture index (Boyd, 1981). These indices are essentially linear combinations of seasonally weighted temperature and precipitation values. In addition, I examined effects of monthly temperature ranges (mean maximummean minimum) for spring and fall. All calculations were based on a year defined to be May-to-April. Because the same transects were sampled each year, I treated transects as blocks. The MAXR selection method in SAS PROC REG (SAS Insti- 
tute, Inc., 1988) was used to determine which climate variables best explained the variation in the wet basin data. Only variables resulting in a substantial increase in $R^{2}$ were included in the final models. When two or more variables produced similar increases in $R^{2}$, variables not resulting in multicollinearity were favored. Finally, models were inspected for presence of interactions and quadratic terms.

I tested the models in three ways. First, I randomly withheld $10 \%$ of the data, re-ran the models on the restricted data set, and compared observed and predicted values for percentage of basins holding water (hereafter, percent wet basins). Next, I withheld two randomly selected transects from each stratum, one transect at a time, re-ran the models on the restricted data sets, and again compared observed and predicted values for percent wet basins. Finally, I used the parkland model to predict percent wet basins on transects in Strata 34 and 35, which were not used in model development, and compared observed and predicted values.

To explore the potential effects of increasing temperatures on number of wet basins in the three regions, I increased temperature variables in the original climate data set by $3{ }^{\circ} \mathrm{C}$ and $6{ }^{\circ} \mathrm{C}$ but held precipitation at observed levels. Likewise, I increased and decreased precipitation by $10 \%$ but held temperatures at observed levels. Finally, I combined the $3{ }^{\circ} \mathrm{C}$ temperature increase and $10 \%$ precipitation increase and decrease to examine the potential for interactive effects in the models.

\section{Results}

\subsection{MODELS}

For parkland, the best model explained $65 \%$ of the variation in percentage of basins holding water:

$$
\begin{aligned}
& \% \text { wet basins } s_{p}=17.12+0.30\left(\text { basin }_{p}\right)+0.16\left(y r p c_{p}\right)-3.47\left(\text { sprtma }_{p}\right) \\
& \quad-3.07\left(\text { fallma }_{p}\right),
\end{aligned}
$$

where basin 1 is the percentage of wet basins counted the previous May, $y r p c$ is total precipitation for the year, sprtma is spring (March through May) mean maximum temperature, and falltma is fall (September through November) mean maximum temperature. The best model for Canadian grassland explained $63 \%$ of the variation in percent wet basins:

$$
\begin{aligned}
& \text { \% wet basins } s_{g c}=61.34+0.19\left(\text { basin }_{g c}\right)+0.15\left(y r p c_{g c}\right) \\
& +0.15\left(\text { fallpc }_{g c}\right)-5.54\left(\text { daprt }_{g c}\right)-1.34\left(\text { fallma }_{g c}\right)
\end{aligned}
$$

where fallpc 1 is fall precipitation during the previous year and daprt is the difference between mean minimum and mean maximum April temperatures. The United 
States grassland model also explained $63 \%$ of the variation in percent wet basins and contained the same variables, but with different coefficients:

$$
\begin{aligned}
& \% \text { wet basins } s_{\text {gus }}=-4.42+0.098\left(\text { basin }_{1}{ }_{\text {gus }}\right)+0.042\left(y r p c_{\text {gus }}\right) \\
& +0.040\left(\text { fallpc }_{\text {gus }}\right)-0.0042\left(\text { daprt }_{\text {gus }}\right)-0.0021\left(\text { falltma }_{\text {gus }}\right) \text {. }
\end{aligned}
$$

No lags greater than one year entered into any model. Moisture indices derived from combinations of climate variables, although explaining substantial amounts of variation on their own, produced multicollinearity when combined with other variables. Because as much variation could be explained by other, more easily interpretable variables, the moisture indices were excluded from these models.

\subsection{TESTING AND VALIDATION}

The models were robust with respect to random and systematic deletion of data. Random deletion of $10 \%$ of the data resulted in Pearson product moment correlations between observed and predicted percent wet basins of $0.81,0.79$, and 0.80 for parkland, Canadian grassland, and United States grassland, respectively. Similarly, average correlations after deletion of one transect were 0.81 (range $0.80-0.81$ ), 0.80 $(0.79-0.80)$, and $0.80(0.79-0.80)$ for parkland, Canadian grassland, and United States grassland, respectively.

Strata 34 and 35 contain a total of 11 transects, all classified as parkland. Climate data for these transects were used to obtain predicted wet basin counts for 1968 through 1990 using the parkland model. Predicted and actual wet basin counts were correlated well $(r=0.77)$.

Because different variables were important in parkland and grassland, it was necessary to determine the degree to which the models differed. To examine this question, I ran the parkland model on Canadian grassland data, and the Canadian grassland model on parkland data. For grassland data in the parkland model, the correlation coefficient between observed and predicted wet basins was 0.70 , compared with 0.80 for grassland data in the grassland model. For parkland data in the grassland model, $r=0.73$, compared with 0.81 for parkland data in the parkland model.

\subsection{EFFECTS OF CHANGING TEMPERATURE AND PRECIPITATION}

The effect of increasing temperature on number of wet basins was not consistent among the three regions (Table II). Temperature had the greatest effect in the parkland; an increase of $3{ }^{\circ} \mathrm{C}$ resulted in a 56\% decline in the average number of wet basins. Canadian grassland was least affected, showing a $15 \%$ decline; United States grassland was intermediate with a $28 \%$ decline in average number of wet basins. Increasing temperature by $6{ }^{\circ} \mathrm{C}$ in the parkland resulted in five years with a predicted average of zero wet basins (Figure 3 ). The same increase in temperature had a less dramatic effect in the grassland areas of Canada and the 
TABLE II

Model projections for increased temperature and precipitation

\begin{tabular}{|c|c|c|c|c|c|c|c|}
\hline \multirow{2}{*}{$\begin{array}{l}\text { Model } \\
\text { area }\end{array}$} & \multicolumn{7}{|c|}{ Mean percent wet basins/year (percent change in parentheses) } \\
\hline & $\begin{array}{l}\text { Observed } \\
1974-87\end{array}$ & $+3{ }^{\circ} \mathrm{C}$ & $+6^{\circ} \mathrm{C}$ & $\begin{array}{l}+10 \% \\
\text { precip. }\end{array}$ & $\begin{array}{l}+3{ }^{\circ} \mathrm{C} \text { and } \\
+10 \% \text { precip. }\end{array}$ & $\begin{array}{l}-10 \% \\
\text { precip. }\end{array}$ & $\begin{array}{l}+3{ }^{\circ} \mathrm{C} \text { and } \\
-10 \% \text { precip. }\end{array}$ \\
\hline Parkland & 51.5 & $\begin{array}{l}22.4 \\
(-56)\end{array}$ & $\begin{array}{c}4.5 \\
(-91)\end{array}$ & $\begin{array}{l}57.2 \\
(+13)\end{array}$ & $\begin{array}{l}31.2 \\
(-38)\end{array}$ & $\begin{array}{l}36.3 \\
(-28)\end{array}$ & $\begin{array}{l}13.4 \\
(-74)\end{array}$ \\
\hline $\begin{array}{l}\text { Canadian } \\
\text { grassland }\end{array}$ & 49.2 & $\begin{array}{l}42.0 \\
(-15)\end{array}$ & $\begin{array}{l}35.1 \\
(-29)\end{array}$ & $\begin{array}{l}55.0 \\
(+12)\end{array}$ & $\begin{array}{l}50.0 \\
(+2)\end{array}$ & $\begin{array}{l}38.9 \\
(-21)\end{array}$ & $\begin{array}{l}34.1 \\
(-31)\end{array}$ \\
\hline $\begin{array}{l}\text { United States } \\
\text { grassland }\end{array}$ & 51.4 & $\begin{array}{l}36.4 \\
(-28)\end{array}$ & $\begin{array}{l}22.8 \\
(-56)\end{array}$ & $\begin{array}{l}57.8 \\
(+12)\end{array}$ & $\begin{array}{l}45.3 \\
(-12)\end{array}$ & $\begin{array}{l}38.2 \\
(-26)\end{array}$ & $\begin{array}{l}22.8 \\
(-56)\end{array}$ \\
\hline
\end{tabular}
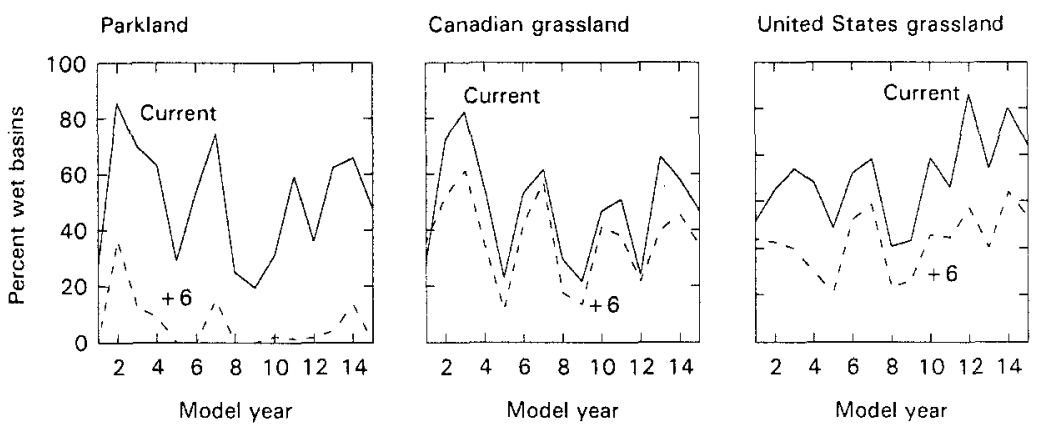

Fig. 3. Yearly estimates of percentage of basins holding water for current climate (solid line) and climate with a $6{ }^{\circ} \mathrm{C}$ increase in temperature (dashed line) in parkland, Canadian grassland, and United States grassland.

United States; numbers of wet basins declined, but the average never fell to zero. During nearly half of the period 1973-1987 a greater percentage of basins held water in the parkland than in United States grassland (Figure 4). Under the scenario of increased temperature, wetland conditions in the parkland are projected to be better than in the United States grassland in only three of the 15 years simulated.

A $10 \%$ increase in precipitation alone resulted in a uniform increase in percentage of wet basins throughout the regions studied (Table II). Parkland wet basins increased by $11 \%$, whereas wet basins in the United States and the Canadian grassland increased by $12 \%$. The $10 \%$ increase in precipitation compensated for some of the effect of increased temperature, but results varied by region (Table II). In the Canadian grassland, a $10 \%$ increase in precipitation nearly balanced a $3{ }^{\circ} \mathrm{C}$ 

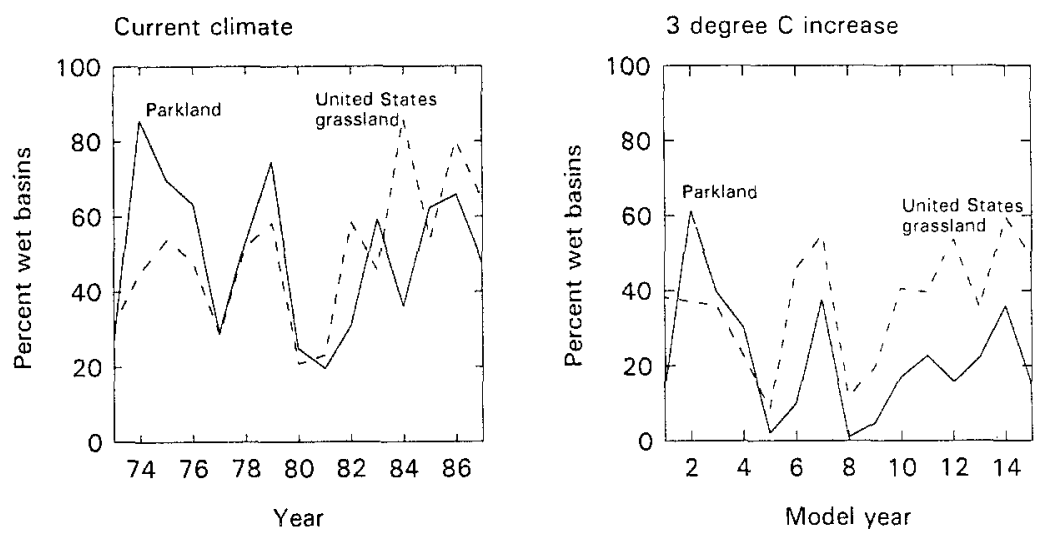

Fig. 4. Comparison of percentage of basins holding water in parkland (solid line) and United States grassland (dashed line) for current climate and climate with a $3{ }^{\circ} \mathrm{C}$ increase in temperature.

increase in temperature. Parkland wet basins still declined by $39 \%$, while United States wet basins declined $12 \%$ from the current average conditions.

Decreasing precipitation alone by $10 \%$ resulted in roughly similar declines in wet basins among the three regions (Table II). When decreased precipitation was examined in concert with a $3{ }^{\circ} \mathrm{C}$ temperature increase, the models again revealed the heightened sensitivity to temperature of wetlands in parkland compared with wetlands in grasslands: parkland wet basins declined by $74 \%$, compared with $31 \%$ and 56\% declines in Canadian and United States grassland wet basins, respectively (Table II).

\section{Discussion}

Despite the influence of other factors, climate explained more than $60 \%$ of the variation in number of wet basins throughout the Prairie Pothole Region. This percentage varied little between grassland and parkland areas. In contrast, the parkland model suggested substantially greater sensitivity to temperature than did the grassland models. Reasons for the difference are speculative, but might include a greater evapotranspiration component in parkland due to more developed vegetation layers and biomass. In particular, willows are a common element of wetland vegetation in the parkland. Transpiration of these phreatophytes has been shown to lower water levels in wetlands (Meyboom, 1966). Higher temperatures may not only increase evapotranspiration directly, but also extend the growing season. Meyboom (1966) observed an abrupt drop in evapotranspiration after the first frost. Penetration of root material through soils in wetlands also may increase soil permeability (Shjeflo, 1968); permeability of glacial till attenuates rapidly below the level of biological activity (Eisenlohr, 1972). The deeper penetration of 
roots of aspen and willow may allow greater seepage, which also increases with increased temperature (Eisenlohr, 1972).

Variables included in the models not only explain relatively large portions of the variation in number of wet basins, they also are intuitively sensible. Percentage of basins holding water is inversely related to temperature and directly related to precipitation and the number of basins that held water the previous year. That spring and fall temperatures proved more important than temperatures at other times of the year is likely related to formation and disintegration of the frost seal. Precipitation that falls after the ground is frozen in the fall and before spring thaw is more likely to remain in the wetland, rather than percolating into the soil (Shjeflo, 1968; Woo and Winter, 1993). The grassland models suggest that April is the critical spring period in these areas, with a smaller temperature spread favoring basin flooding.

The similarity among the three regions in response to precipitation may be explained by the physical similarities of the basins themselves. Northern prairie wetlands are depressions formed by glacial action during the Wisconsin glaciation. The Prairie Pothole Region as a whole contains similar geomorphology, a mixture of glacial till and outwash (Eisenlohr, 1972; National Wetlands Working Group, 1988). Basins are poorly integrated and lack overland drainage between basins. Water enters the basins primarily as precipitation falling directly on the flooded portion of the basin, or as within-basin runoff (Eisenlohr, 1972). Thus, the shape and depth of the basin, rather than complex drainage systems, determine the amount of water that accumulates.

Recent work (Karl et al., 1991b) has documented that observed warming trends are occurring in minimum rather than maximum temperatures. The importance of this observation with respect to wetland dynamics cannot be addressed directly with these models. However, mean minimum monthly temperatures were evaluated in model development and found to fit the data less well than the mean maximum temperatures ultimately included. This is not to say that minimum temperatures are unimportant. Extension of the frost-free period that would accompany an increase in minimum temperatures would result in a longer growing season and thus a longer period during which plants would transpire. Daily evapotranspiration might not be as high if minimum rather than maximum temperatures increased, however. The ultimate effect on water balance would depend on the relative magnitudes of possibly lower daily evapotranspiration summed over a longer season (with increased minimum temperatures) and potentially higher daily evapotranspiration over a relatively shorter season (with increased maximum temperatures).

The greater vulnerability of parkland than grassland basins to increased temperature has important implications for waterfowl that rely on these wetlands for breeding habitat. Basin density in parkland is two to three times as high as that in the grassland regions (Table I), representing a significant reservoir of breeding habitat. Studies of settling patterns suggest that many duck species enter the breeding grounds from the south, stopping at the first available habitat (Johnson and Grier, 1988). Birds not finding suitable habitat in the grasslands move northward 
into parkland habitat. Other species, such as canvasbacks (Aythya valisineria), use parkland as their primary breeding area, dispersing north or northwest if wetland conditions in the parkland are not suitable for nesting (Johnson and Grier, 1988). This response will not be universally acceptable if wetlands respond to climate change as I have modelled. One important consequence of this geographical difference in wetland response to temperature is the decreased probability of finding better conditions as waterfowl migrate farther north (Figure 4).

Anticipated changes in climate will affect not only the overall number of wet basins, but also are likely to change the vegetative structure within the wetlands. Poiani and Johnson (1993) simulated vegetation development in a semipermanently flooded wetland in North Dakota using climate change scenarios of 0 to $+4^{\circ} \mathrm{C}$ and -20 to $+20 \%$ change in precipitation. With a $2{ }^{\circ} \mathrm{C}$ rise in temperature and an 11-year simulation period, they found that all precipitation levels except the $20 \%$ increase produced drawdown conditions in which seedlings of emergent plant species spread throughout the wetland. With a $4{ }^{\circ} \mathrm{C}$ rise in temperature the wetland was dry $38 \%$ of the time. The models of the current study and those of Poiani and Johnson suggest that anticipated climate changes may result in both fewer and lower-quality wetlands for waterfowl production. Neither study addresses the potential loss of temporary wetlands, which provide important habitat for migrating waterfowl and shorebirds.

Landscape-level models such as those I present would benefit from a better understanding of soil and groundwater interactions with surface water. For example, most of the soils in the glaciated prairie are built on till comprised of silt and clay, and are thus quite impermeable when moist but crack readily upon drying (Winter, 1989). The number of fractures in the soil may vary both geographically as a function of clay content, and in response to varying lengths of drought. The relationships may or may not be linear; a significant interaction seems likely. Terms that summarize these relationships would help refine model projections.

In all likelihood, the models described here are conservative in that groundwater depletion is not considered. Because wetland numbers are bounded at the lower end by zero, a continued moisture deficit after drying of the basin is not taken into account. If subsequent precipitation replenishes the local water table before adding to surface water, the number of wet basins could be less than projected.

Although the temperature and precipitation values used in these simulations are within the range predicted by general circulation models for the northern Great Plains, projections can be only as good as the data used in making them, and regional climate models are still in their infancy (Grotch, 1988; Cushman and Spring, 1989). In addition, these wetland models are empirically-based; projections outside the range of values used to develop the models cannot include factors that only come into play at these extreme values. Some studies have suggested extensive shifts in vegetation resulting from climate-induced changes in fire and disturbance regimes (Overpeck et al., 1990; Hogenbirk and Wein, 1991); disruption of parkland and grassland vegetation types would certainly influence wetland dynamics in ways 
not anticipated by models dealing solely with climate. Other parameters associated with the accumulation of greenhouse gases, such as carbon dioxide fertilization of plants and increasing ultraviolet $B$ radiation, and their influence on wetland dynamics (Larson, 1994), are also beyond the scope of these models.

The value of models such as these lies less in the accuracy of their projections than in the sensitivities they reveal. These models can suggest areas of concern in the future, independent of the actual magnitude of climatic change. In particular, the models suggest the importance of conserving wetlands in grassland areas of the Prairie Pothole Region that may be less affected by climatic changes. Empirical studies of wetlands throughout the northern Great Plains are needed to discern the reasons for geographic differences in wetland sensitivities to climate.

\section{Acknowledgements}

I thank R. Greenwood, L. Igl, D. Johnson, J. Price, and two anonymous reviewers for helpful comments on the manuscript and W. Newton for statistical advice. J. Bladen kindly provided basin counts and transect locations. This study would not have been possible without the dedicated work of Flyway Biologists in Canada and the United States who conduct the annual aerial surveys.

\section{References}

Batt, B. D. J., Anderson, M. G., Anderson, C. D., and Caswell, F. D.: 1989, 'The Use of Prairie Potholes by North American Ducks', in van der Valk, A. (ed.), Northern Prairie Wetlands, Iowa State University Press, Ames, Iowa, pp. 204-227.

Boyd, H.: 1981, 'Prairie Dabbling Ducks, 1941-1990', Canad. Wildlife Service Wildlife Notes.

Cess, R. D., Zhang, M.-H., Potter, G. L., Barker, H. W., Colman, R. A., Dazlich, D. A., Del Genio, A. D., Esch, M., Fraser, J. R., Galin, V., Gates, W. L., Hack, J. J., Ingram, W. J., Kiehl, J. T., Lacis, A. A., LeTreut, H., Li, Z.-X., Liang, X.-Z., Mahfouf, J.-F., McAvaney, B. J., Meleshko, V. P., Morcrette, J.-J., Randall, D. A., Roeckner, E., Royer, J.-F., Sokolov, A. P., Sporyshev, P. V., Taylor, K. E., Wang, W.-C., and Wetherald, R. T.: 1993, 'Uncertainties in Carbon Dioxide Radiative Forcing in Atmospheric General Circulation Models', Science 262, 1252-1255.

Cushman, R. M. and Spring, P. N.: 1989, 'Differences among Model Simulations of Climate Change on the Scale of Resource Regions', Environ. Manage. 13, 789-7995.

Eisenlohr, W. S., Jr.: 1972, 'Hydrologic Investigations of Prairie Potholes in North Dakota, 1959-68', U.S. Geol. Surv. Prof. Pap. 585-A.

Golden Software, Inc.: 1991, Surfer, Version 4, Golden Software, Inc., Golden, Colorado.

Grotch, S. L.: 1988, 'Regional Intercomparisons of General Circulation Model Predictions and Historical Climate Data', U.S. Dep. Energy DOE/NBB 0084.

Henny, C. J., Anderson, D. R., and Pospahala, R. S.: 1972, 'Aerial Surveys of Waterfowl Production in North America, 1955-1971', U.S. Fish Wildl. Serv. Spec. Sci. Rep. Wildl. 160.

Hogenbirk, J. C. and Wein, R. W.: 1991, 'Fire and Drought Experiments in Northern Wetlands: A Climate Change Analogue', Can. J. Bot. 69, 1991-1997.

Isaaks, E. H. and Srivastava, R. M.: 1989, An Introduction to Applied Geostatistics, Oxford University Press, New York.

Johnson, D. H. and Grier, J, W.: 1988, 'Determinants of Breeding Distributions of Ducks', Wildl. Monogr. 100, 1-37. 
Karl, T. R., Heim, R. R., Jr. and Quayle, R. G.: 1991a, 'The Greenhouse Effect in Central North America: If Not Now, When?' Science 251, 1058-1061.

Karl, T. R., Kukla, G., Razuvayev, V. N., Changery, M. J., Quayle, R. G., Heim, R. R., Easterling, D. R., and Fu, C. B.: 1991b, 'Global Warming: Evidence for Asymmetrical Diurnal Temperature Change', Geophys. Res. Lett. 18, 2253-2256.

Karl, T. R., Williams, C. N., Jr. and Quinlan, F. T.: 1990, 'United States Historical Climatology Network (HCN) Serial Temperature and Precipitation Data', Oak Ridge National Laboratory NDP 091/R1.

Kiel, W. H., Jr., Hawkins, A. S., and Perret, N. G.: 1972, 'Waterfowl Habitat Trends in the Aspen Parkland of Manitoba', Canadian Wildl. Serv. Rep. Ser. 18.

Larson, D. L.: 1994, 'Potential Effects of Anthropogenic Greenhouse Gases on Avian Habitats and Populations in the Northern Great Plains', Am. Midl. Nat. 131, 330-346.

McCabe, G. J., Jr. and Wolock, D. M.: 1991, 'Detectability of the Effects of a Hypothetical Temperature Increase on the Thornthwaite Moisture Index', J. Hydrol. 125, 25-35.

Meyboom, P.: 1966, 'Unsteady Groundwater Flow near a Willow Ring in Hummocky Moraine', $J$. Hydrol. 4, 38-62.

National Wetlands Working Group: 1988, 'Wetlands of Canada', Sustainable Development Branch, Environment Canada Ecological Land Classification Series 24.

Overpeck, J. T., Rind, D., and Goldberg, R.: 1990, 'Climate-Induced Changes in Forest Disturbance and Vegetation', Nature 343, 51-53.

Poiani, K. A. and Johnson, W. C.: 1991, 'Global Warming and Prairie Wetlands: Potential Consequences for Waterfowl Habitat', BioScience 41, 611-618.

Poiani, K. A. and Johnson, W. C.: 1993, 'Potential Effects of Climate Change on a Semi-Permanent Prairie Wetland', Clim. Change 24, 213-232.

Sargeant, A. B., Greenwood, R. J., Sovada, M. A., and Shaffer, T. L.: 1993, 'Distribution and Abundance of Predators That Affect Duck Production - Prairie Pothole Region', U.S. Fish Wildl. Serv. Res. Publ. 194.

SAS Institute, Inc.: 1988, SAS/STAT User's Guide, Release 6.03 Edition, SAS Institute Inc., Cary, North Carolina.

Shjeflo, J. B.: 1968, 'Evapotranspiration and the Water Budget of Prairie Potholes in North Dakota', U.S. Geol. Surv. Prof. Pap. 585-B.

Smith, J. B. and Tirpak, D. A.: 1990, The Potential Effects of Global Climate Change on the United States, Hemisphere Publishing Corp., New York.

Stewart, R. E. and Kantrud, H. A.: 1971, 'Classification of Natural Ponds and Lakes in the Glaciated Prairie Region', U.S. Fish Wildl. Serv. Resour. Publ. 92.

Winter, T. C.: 1989, 'Hydrologic Studies of Wetlands in the Northem Prairie', in van der Valk, A. (ed.), Northern Prairie Wetlands, Iowa State University Press, Ames, Iowa, pp. 16-54.

Woo, M. K. and Winter, T. C.: 1993, 'The Role of Permafrost and Seasonal Frost in the Hydrology of Northern Wetlands in North America', J. Hydrol. 141, 5-31.

(Received 9 March, 1994; in revised form 30 December, 1994) 